\title{
Factors Influencing College Students' Financial Behaviors in Turkey: Evidence from a National Survey
}

\author{
Elif Akben-Selcuk ${ }^{1}$ \\ ${ }^{1}$ Department of Business Administration, Kadir Has University, Istanbul, Turkey \\ Correspondence: Elif Akben-Selcuk, Kadir Has University, School of Economics, Administrative and Social \\ Sciences, Cibali, Istanbul, 34083, Turkey. Tel: 90-212-533-6532. E-mail: elif.akben@khas.edu.tr
}

Received: March 25, 2015

Accepted: March 31, 2015

Online Published: May 25, 2015

doi:10.5539/ijef.v7n6p87

URL: http://dx.doi.org/10.5539/ijef.v7n6p87

\begin{abstract}
The purpose of this study was to investigate the factors influencing financial behaviors among college students in Turkey. Data was obtained from a nationwide survey of 1539 students (748 women, 791 men; $M$ age $=22.01$ yr., $S D=2.44$ ) and three financial behaviors were analyzed: paying bills on time, having a budget in place, and saving for the future. Logistic regression results showed that students who are more financially literate are more likely to exhibit the three positive financial behaviors. Parental teaching of finance and positive attitudes towards money were also found to be significant predictors of positive financial behaviors. A significant difference between male and female students was only observed for budgeting behavior and male students were found to be less likely to have a budget in place to control their finances. Finance courses taken in college or high school and work experience were positively related to saving behavior, but unrelated to timely payment or budgeting. Finally, students' class rank was not found to be significantly related to any of the financial behaviors. Policy implications are provided.
\end{abstract}

Keywords: financial behavior, financial literacy, college students, Turkey

\section{Introduction}

University or college students are in a distinct period of their lives where they start to manage their money independently without parental supervision. The majority of these young people start to deal with monetary challenges such as paying bills, keeping a budget, or having a credit card to their own names for the first time. The financial behaviors that college students learn during these years are likely to influence the decisions they make in the future (Shim, Xiao, Barber, \& Lyons, 2009). Research has shown that positive financial behaviors are related to improved financial well-being (Joo \& Grable, 2004), decreased financial stress (Hayhoe, Leach, Turner, Bruin, \& Lawrance, 2000) and higher self-esteem (Lange \& Byrd, 1998). Because of these far-reaching consequences of financial behaviors, it is important to investigate which factors have a significant impact on them in order to increase students' general quality of life in later years (Gutter \& Copur, 2011; Xiao, Tang, \& Shim, 2008).

Previous literature contains some investigation of college students' financial behaviors and mostly focuses on developed countries such as the USA. In one such study, Cude et al. (2006) investigated credit card behavior using data collected from a sample of 1,891 college students in two universities in the USA. Results showed that students having a credit card, minorities and senior students were more likely to be financially distressed. On the other hand, students with higher GPAs and married parents were more likely to be financially fit. Students reported that the most significant influence on their financial management behaviors was their parents. In another study, Hancock, Jorgensen, and Swanson (2012) used data collected from 413 students in seven universities in the USA and found that students who were juniors or seniors, who had parents arguing about finances at home and who were comfortable making the minimum payments were more likely have higher levels of credit card debt. Using the same dataset, Jorgensen and Savla (2010) found that parental influence had an indirect effect on the financial behaviors of college students mediated through financial attitudes. The importance of parental involvement for credit card behaviors of college students was also confirmed by Palmer, Pinto, and Parente (2001) who used data from a sample 355 college students in the USA and showed that parental involvement prior to the acquisition of the credit card reduces students' outstanding card debt while post-acquisition involvement has the opposite effect. 
In another study, Hayhoe et al. (2000) collected data from a sample of 480 students in six state universities in the USA and found that female students, those with higher incomes and those with positive attitudes towards the use of credit were more likely to display risky credit card behaviors. Later on, Lyons (2004) investigated credit card practices in a sample of 835 college students and found that gender, ethnicity, financial independence, total amount of debt and credit card acquisition prior to the college were significant predictors of risky financial behaviors. In a more recent study, Xiao, Ahn, Serido, and Shim (2014) used data collected at two points in time from a group of college students in a state university in the USA and analyzed risky borrowing and paying behaviors. Results showed that subjective and objective finance knowledge reduced the likelihood of displaying negative financial behaviors. In addition, higher GPA was correlated with fewer risky paying behaviors and male students were found to display more risky financial behaviors in general.

In a study focusing on psychological variables, Norvilitis, Merwin, Osberg, Roehling, and Kamas (2006) investigated the factors affecting credit-card debt in 448 students from five US universities. Older students, students with more credit cards and those who are less knowledgeable about financial issues reported a higher amount of credit card debt. In addition, delay of gratification and attitudes towards credit card use were positively related to debt levels. In another study focusing on psychological variables, Shim et al. (2009) found that self-actualizing personal values and financial education at home or at school had important roles in shaping financial attitudes and intentions among young adults. This finding was also confirmed by Shim, Barber, Card, Xiao, and Serido (2010) who, through structural equation modeling, found that parents, work experience and high school financial education were significantly related to young adults' financial attitudes and behaviors. The authors further showed parents played a greater role than work experience and school education as financial socialization agents. The findings of the study also supported a four-level model where early financial socialization is correlated with financial learning which affects financial attitudes, which in turn, affect financial behaviors.

In one of the rare studies using data from developing countries, Sabri, MacDonald, Hira, and Masud (2010) collected data from 11 universities in Malaysia and showed that higher financial literacy levels were positively related to saving behavior and negatively related to financial problems among college students. They also found that financial experience before college can create bad financial habits for students. In a subsequent study, Sabri, Cook, and Gudmunson (2012) found that saving habits, financial literacy and financial socialization agents increase students' financial well-being levels including their current financial situation and financial management skills.

As is clear from the preceding discussion, empirical evidence on the financial behaviors of college students in developing countries is limited. However, students in these countries might be affected by unique regional and cultural factors that shape their financial behaviors. Hence, it is important to test whether the findings obtained within the US context apply to other countries as well. In that respect, Turkey constitutes a useful example. First, in the Turkish culture, parents tend to isolate their children from monetary issues and financially support them until they get married (Yesilada \& Ucel, 2009). Accordingly, factors affecting financial behaviors among the young in Turkey might differ from the factors in developed countries. Second, consumers in Turkey have limited experience with formal financial systems (OECD, 2012). Hence, analyzing the predictors of positive financial behaviors among Turkish financial consumers, especially the young, has both theoretical and practical significance. The issue is even more important considering the fact that Turkey has experienced an increase in the number and complexity of financial products in recent years (Financial Corps, 2014). Finally, despite the fact that Turkey has been one of the fastest growing countries in the world in the recent decade, its average savings rate remains low (IMF, 2013). Hence, encouraging positive financial behaviors would have macro-level effects for the country as well.

Despite the importance of university or college students as a customer segment for financial products and services in Turkey, research on their financial behaviors is very limited. In a study on adults, Sevim, Temizel, and Sayılır (2012) demonstrated that higher financial literacy results in less likelihood of excessive borrowing behavior using data from a sample of 550 adults in the city of Eskişehir in Turkey. In another study, Akben-Selcuk and Altiok-Yilmaz (2014) analysed a sample of 853 students from a Turkish university and found that their financial literacy is low as evidence by an average of $45 \%$ of correct responses on a 27 -item financial knowledge scale. The authors further demonstrated that formal finance education in college, a deep approach to learning, and financial teaching by parents were significant predictors of better financial literacy scores. However, no direct investigation of students' financial behaviors was made. To the best of our knowledge, no studies to date specifically focused on the financial behaviors of college students in Turkey. The present study attempts to fill this gap in the literature. The specific objectives of the study are to analyze the factors affecting 
the following three behaviors: paying bills on time, having a budget in place to control finances, and saving for the future. Based on the findings of previous studies in the literature, the following three hypotheses were developed.

Hypothesis 1. Students who are more financially literate will be more likely to display positive financial behaviors.

Hypothesis 2. Financial socialization through courses taken, parental direct teaching of finance, and work experience will have a positive impact on the likelihood of displaying positive financial behaviors.

Hypothesis 3. Students with positive attitudes towards money will be more likely to display positive financial behaviors.

\section{Method}

\subsection{Participants and Procedure}

The data for this study comes from a nationwide survey of 1539 college students in Turkey. The sample consists of 748 female and 791 male students from 3 private and 14 public universities. The average age of the students in our sample is 22.01 years $(S D=2.44$ years). The percentages of freshmen, sophomore, junior and senior students in our sample are $27 \%, 21 \%, 19 \%$ and $33 \%$ respectively. Data were collected on campus, through face-to-face interviews, which lasted approximately 20 minutes per respondent. The survey form included questions related to students' financial behaviors, financial attitudes and financial knowledge levels as well as questions on socio-demographic factors and several psychological variables. Before being administering the survey to the final sample, a pilot study was conducted on 50 respondents in order to refine the items and eliminate ambiguities.

\subsection{Measures}

\subsubsection{Dependent Variables}

Three financial behaviors were the focus of this study: paying bills on time, having a budget in place and saving for the future. Students were asked to state how often they "pay their bills on time", "have budget in place to manage their finances", and "have been actively saving for the future" on a scale from 1 to 5 (1: never, 5: always). Students putting themselves at 4 or 5 on the scale were considered to display a given behavior while those putting themselves at 1,2 or 3 were assumed not to display the behavior. Accordingly, three dummy variables were constructed for each of the three financial behaviors. The dummies take the value of "1" for those who display a given behavior and " 0 " otherwise.

\subsubsection{Independent Variables}

The first independent variable, which was considered as a potential predictor of positive financial behaviors, is students' financial literacy levels. To measure financial literacy, students were asked to answer 27 multiple choice questions on several personal finance domains including general money management, saving and borroring, investment and insurance. The items came from previously validated international financial literacy surveys in the literature (Chen \& Volpe, 1998, 2002; Danes \& Hira, 1987; Hancock et al., 2012; Jorgensen \& Savla, 2010; Mandell, 2009; Volpe, Chen, \& Pavlicko, 1996). The questions were first translated into Turkish and then independently back translated into English in order to check for any inconsistencies. Students' financial literacy scores were calculated as the percentage of correct responses to the 27 questions. Missing responses were treated as incorrect. The reliability of the financial literacy scale as measured by Cronbach's alpha was found to be 0.68 , which is considered acceptable (Kline, 2000).

The second group of independent variables includes financial socialization agents, which are the school, the family and work experience. In order to capture the effect of school on financial behaviors, the variable Course was defined to take the value of "1" for students who took at least one finance related class in college or high school. Direct teaching of finance by parents was measured as in Shim et al. (2009) by asking the students to indicate whether their parents talked to them about the following personal finance topics while growing up: the importance of savings, the family spending plan, the student's own spending, and the use of credit. Based on the responses, the variable Parental ranging from 0 to 4 was generated, where a score of 0 indicates no discussion in any of the areas, while a score of 4 indicates discussion in all 4 areas. Students were also asked whether they have already worked in a paid job, either part-time or full-time. Based on their responses, the dummy variable Work experience was defined to take the value of " 1 " for respondents who have already been employed and " 0 " otherwise.

Thirdly, students' attitude towards money was considered as a potential factor affecting financial behavior. To 
operationalize that construct, the 12-item "Money Ethic Scale" developed by Tang (1995) was used. Students were asked to indicate the extent to which they agree with the 12 statements on a scale from 1 to 5 (1: completely disagree, 5: completely agree). The scale comprised 3 major components: affective (e.g. "Money is the root of all evil"), cognitive (e.g. "Money is a symbol of success") and behavioral (e.g. "I budget my money very well"). Students' money attitude scores were calculated as the average of their responses to the 12 statements. Two of the items representing negative attitudes were reverse coded so that higher scores represent more positive attitudes towards money. The Cronbach's alpha value of the scale in our sample was 0.72 , which is considered good (Kline, 2000).

Finally, students' gender and class rank were included into the analysis as control variables. The variable Gender takes the value of " 1 " for male students and " 0 " for female students. For class rank, four dummy variables were constructed as follows: Class 1 takes the value of 1 if the student is a freshman or is in the English preparatory class, Class 2 takes the value of 1 if the student is a sophomore, Class 3 takes the value of 1 if the student is a junior and Class 4 takes the value of 1 if the student is a senior. Class 1 was left out of the regression analysis as the reference category.

\subsection{Analysis}

The categorical dependent variables of the study necessitated the use of logistic regression analysis. Three separate equations were fitted to predict the probability of paying bills on time, the probability of budgeting, and the probability of saving from selected predictors described previously. A maxium likelihood estimation procedure was used to obtain parameter estimates.

Since the interpretation of coefficients is difficult in the case of logistic regression, model results are reported in terms of odd ratios which are defined as the ratio of the probability that an event will occur (in our case a behavior will be displayed) to the probability that it will not. Values greater than 1 indicate that a given factor will increase the odds while values less than 1 indicate that the factor will decrease the odds (Hair, Black, Babin, \& Anderson, 2009).

Before proceeding with the analysis, multicollinearity among predictor variables was checked by ensuring that tolerance values did not exceed 0.1 and that variance inflation factors were below 10 as suggested by Hair et al. (2009)

\section{Results}

\subsection{Descriptive Statistics}

According to the results of our survey, $52 \%$ of the respondents reported that they pay their bills on time, $43 \%$ indicated that they have a budget in place to control their finances and only $33 \%$ reported that they have been actively saving. When the descriptive statistics for independent variables are analyzed, it can be seen that the average financial knowledge score in the sample is $42.87 \%(S D=15.19 \%)$ meaning that an average student could not answer even half of the questions correctly. Regarding financial socialization sources, $23 \%$ of the students have taken a finance class while $68 \%$ reported having some type of work experience. The average parental teaching score is $1.81(S D=1.02)$ out of 4 . Finally, the mean score on the money ethic scale is $3.11(S D$ $=0.54$ ) out of 5 .

\subsection{Logistic Regression Results}

Table 1 that follows contains the results of our first logistic regression predicting the likelihood of paying bills on time. The full model was statistically significant, $\chi^{2}(9, N=1539)=39.45, \mathrm{p}<0.001$, meaning that it could discern differences between students who pay their bills on time and those who do not. The model was able to explain between 11.85\% (Cox and Snell R-square) and 15.68\% (Nagelkerke R-square) of the variance and correctly classified $75 \%$ of the cases.

Three of the independent variables analysed were found to be statistically significant. The strongest predictor for paying bills on time was financial literacy, with an odds ratio of 2.01. This result indicates that for a one-point increase on the financial literacy score, students were 2.01 times more likely to report paying their bills on time. Direct teaching of finance by parents also has a positive and significant effect on the probability of timely payment. For every additional financial issue discussed with parents, students were 1.81 times more likely to pay their bills on time. Finally, students with positive attitudes towards money are more likely to pay their bills on time. For every additional unit on the money ethic scale, students were 1.31 times more likely to report timely payment. 
Table 1. Logistic regression predicting likelihood of paying bills on time

\begin{tabular}{lcccccc}
\hline & Odds ratio & S.E. & $\mathrm{z}$ & $\mathrm{P}>\mathrm{z}$ & \multicolumn{2}{c}{$95 \%$ CI for odds ratio } \\
& & & & & Lower & Upper \\
\hline Gender & 1.02 & 0.11 & 0.15 & 0.88 & 0.82 & 1.25 \\
Financial literacy & 2.01 & 0.00 & 2.85 & 0.00 & 2.00 & 2.02 \\
Parental teaching & 1.81 & 0.04 & 4.08 & 0.00 & 1.74 & 1.90 \\
Sophomore & 0.85 & 0.13 & -1.11 & 0.27 & 0.63 & 1.14 \\
Junior & 0.84 & 0.13 & -1.11 & 0.27 & 0.62 & 1.14 \\
Senior & 0.87 & 0.12 & -1.05 & 0.29 & 0.66 & 1.13 \\
Work experience & 0.99 & 0.11 & -0.10 & 0.92 & 0.79 & 1.24 \\
Course & 0.86 & 0.12 & -1.12 & 0.26 & 0.66 & 1.12 \\
Money attitudes & 1.31 & 0.13 & 2.77 & 0.01 & 1.08 & 1.58 \\
Constant & 0.55 & 0.20 & -1.64 & 0.10 & 0.27 & 1.12 \\
\hline
\end{tabular}

Table 2 below presents the results of the second regression analysis predicting the likelihood of having a budget in place. The full model was statistically significant, $\chi^{2}(9, N=1539)=65.17, \mathrm{p}<0.001$, meaning that it could discern differences between students who have a budget to control their finances and those who do not. The model was able to explain between $13.1 \%$ (Cox and Snell R-square) and 18.87\% (Nagelkerke R-square) of the variance and correctly classified $77 \%$ of the cases.

Four of the independent variables were found to be statistically significant. First, as in the first model, students with higher financial literacy scores were more likely to have a budget. The odds ratio was 2.02 meaning that for a one-point increase on the financial literacy score, students were 2.02 times more likely to report having a budget in place. Direct teaching of finance by parents also had a positive and significant effect on the probability of budgeting. For every additional financial issue discussed with parents, students were 1.79 times more likely to have a budget. Thirdly, students with positive attitudes towards money were more likely to budget. For every additional unit on the money ethic scale, students were 1.54 times more likely to report having a budget. Finally, the odds ratio for gender was 0.82 . Since it is lower than 1 , this indicates that male students are 0.82 times less likely to report having a budget.

Table 2. Logistic regression predicting likelihood of budgeting

\begin{tabular}{|c|c|c|c|c|c|c|}
\hline & \multirow[t]{2}{*}{ Odds ratio } & \multirow[t]{2}{*}{ Std. Err. } & \multirow[t]{2}{*}{$\mathrm{z}$} & \multirow[t]{2}{*}{$\mathrm{P}>\mathrm{z}$} & \multicolumn{2}{|c|}{$95 \% \mathrm{CI}$ for odds ratio } \\
\hline & & & & & Lower & Upper \\
\hline Gender & 0.82 & 0.09 & 1.84 & 0.07 & 0.66 & 1.01 \\
\hline Financial literacy & 2.02 & 0.00 & 4.49 & 0.00 & 2.01 & 2.02 \\
\hline Parental teaching & 1.79 & 0.04 & 4.43 & 0.00 & 1.71 & 1.88 \\
\hline Sophomore & 1.25 & 0.19 & 1.43 & 0.15 & 0.92 & 1.69 \\
\hline Junior & 1.28 & 0.21 & 1.55 & 0.12 & 0.94 & 1.76 \\
\hline Senior & 1.28 & 0.18 & 1.54 & 0.12 & 0.97 & 1.68 \\
\hline Work experience & 0.93 & 0.11 & -0.61 & 0.55 & 0.74 & 1.17 \\
\hline Course & 0.82 & 0.10 & -1.53 & 0.13 & 0.64 & 1.06 \\
\hline Money attitudes & 1.54 & 0.15 & 4.36 & 0.00 & 1.27 & 1.87 \\
\hline Constant & 0.15 & 0.06 & -5.06 & 0.00 & 0.07 & 0.31 \\
\hline
\end{tabular}

Table 3 that follows presents the results of the third and final regression analysis predicting the likelihood of saving for the future. The full model was statistically significant, $\chi^{2}(9, N=1539)=63.13, \mathrm{p}<0.001$, meaning that it could discern differences between students who have save for the future and those who do not. The model was able to explain between 13.23\% (Cox and Snell R-square) and 19.61\% (Nagelkerke R-square) of the variance and correctly classified $78 \%$ of the cases.

Five of the independent variables were found to be statistically significant. First, students with higher financial literacy scores were more likely to save. The odds ratio was 2.01 meaning that for a one-point increase on the financial literacy score, students were 2.01 times more likely to report saving. Direct teaching of finance by parents also had a positive and significant effect on the probability of saving. For every additional financial issue discussed with parents, students were 1.78 times more likely to save. Thirdly, students with positive attitudes 
towards money were more likely to save. For every additional unit on the money ethic scale, students were 1.69 times more likely to report saving. The odds ratio for work experience was 1.69 , meaning that students who have already worked in a paid job were 1.69 times more likely to save than those without any work experience were. Finally, students having taken finance related classes are 1.7 times more likely to report saving.

Table 3. Logistic regression predicting likelihood of saving

\begin{tabular}{|c|c|c|c|c|c|c|}
\hline & \multirow[t]{2}{*}{ Odds ratio } & \multirow[t]{2}{*}{ Std. Err. } & \multirow[t]{2}{*}{$\mathrm{z}$} & \multirow[t]{2}{*}{$\mathrm{P}>\mathrm{Z}$} & \multicolumn{2}{|c|}{$95 \%$ CI for odds ratio } \\
\hline & & & & & Lower & Upper \\
\hline Gender & 1.07 & 0.12 & 0.62 & 0.54 & 0.86 & 1.34 \\
\hline Financial literacy & 2.01 & 0.00 & 1.86 & 0.06 & 2.00 & 2.01 \\
\hline Parental teaching & 1.78 & 0.04 & 4.30 & 0.00 & 1.70 & 1.88 \\
\hline Sophomore & 1.23 & 0.20 & 1.30 & 0.19 & 0.90 & 1.68 \\
\hline Junior & 0.99 & 0.17 & -0.04 & 0.97 & 0.71 & 1.39 \\
\hline Senior & 1.03 & 0.15 & 0.22 & 0.83 & 0.77 & 1.38 \\
\hline Work experience & 1.69 & 0.08 & 3.10 & 0.00 & 1.54 & 1.87 \\
\hline Course & 1.70 & 0.09 & 2.86 & 0.00 & 1.55 & 1.89 \\
\hline Money attitudes & 1.69 & 0.18 & 5.03 & 0.00 & 1.38 & 2.08 \\
\hline Constant & 0.13 & 0.05 & -5.10 & 0.00 & 0.06 & 0.29 \\
\hline
\end{tabular}

\section{Conclusion and Discussion}

The objective of the present study was to investigate the factors, which influence financial behaviors of college students in Turkey. The focus was on three behaviors, namely, paying bills on time, having a budget in place to manage finances and actively saving for the future.

Several important findings emerged from our analysis. First, financial literacy of the students, as measured by their scores on a financial knowledge test, had a positive and significant impact on students' likelihood of displaying each of the three positive financial behaviors. Hence, the first hypothesis was supported. Based on this result, policy makers and educators should try to take actions to increase financial knowledge among Turkish college students so that they display more positive financial behaviors in the future.

Second, parental teaching of finance was found to have a positive impact on the probability of displaying all three financial behaviors, providing support for the second hypothesis. This result is very important and implies that financial education should start at home. Parents need to be aware of the role they are playing in the financial socialization of their children and should discuss financial matters with them while growing up, instead of isolating them from realities of real life as is a common practice in the Turkish culture. The finding also means that policy makers should find ways to include parents in the financial education of their children. Informing parents on personal finance issues so that they acquire sound financial knowledge to transmit and encouraging them to discuss those issues with their children would be good ways to encourage positive financial behaviors among the young in Turkey (Lusardi, Mitchell, \& Curto, 2010). Freshmen orientations on campuses including finance sessions for students and parents or online resources for parents and college students could also be particularly useful ideas (Cude et al., 2006).

Attitude towards money was also found to be a significant predictor of college students' financial behaviors, providing support for the third hypothesis. Students with more positive attitudes towards money were more likely to report paying bills on time, having a budget in place and saving for the future. This result implies that while it is important to talk about money with children while they are growing up, it is crucial to make sure that this is accomplished in a positive manner. Parents and educators should be encouraged to show positive and favourable attitudes about money to students.

Another finding that emerged from our analysis is that male students are less likely to have a budget in place to control their finances. However, gender did not have a statistically significant impact on the likelihood of paying bills on time and saving for the future. Finance related courses taken in high school or college had a positive impact on the probability of saving for the future but did not have an impact on the likelihood of displaying the other two behaviors. Another factor, which had a positive and significant impact on saving behavior, was work experience. Based on these results, offering more courses to students as electives or as a requirement to graduate seems a useful option to improve students' financial behaviors. Similarly, universities should find ways to increase work experience of students by offering internship or on-campus employment opportunities. 
The present study suffers from the following limitations. First, due to the cross-sectional design of the study no causal relationships can be assumed. Another limitation is that only student data were collected. Data from both students and parents could be useful to operationalize parental influences. Third, social desirability bias might have affected some of our results since students might be reluctant to report negative financial behaviors in an attempt to appear socially correct. In addition to addressing these limitations, further research could investigate the effect of additional explanatory variables such as motivational factors as well as how financial attitudes mediate the relationship between knowledge and behavior among college students in Turkey.

\section{Acknowledgements}

Financial support from The Scientific and Technological Research Council of Turkey (TÜBİTAK) is greatfully acknowledged (Project 113K767).

\section{References}

Akben-Selcuk, E., \& Altiok-Yilmaz, A. (2014). Financial literacy among Turkish college students: The role of formal education, learning approaches and parental teaching. Psychological Reports, 115(2), 351-371. http://dx.doi.org/ 10.2466/31.11.PR0.115c18z3

Chen, H., \& Volpe, R. P. (1998). An analysis of personal financial literacy among college students. Financial Services Review, 7(2), 107-128. http://dx.doi.org/10.1016/s1057-0810(99)80006-7

Chen, H., \& Volpe, R. P. (2002). Gender differences in personal financial literacy among college students. Financial Services Review, 11(3), 289-307.

Cude, B., Lawrence, F., Lyons, A., Metzger, K., LeJeune, E., Marks, L., \& Machtmes, K. (2006). College Students and Financial Literacy: What They Know and What We Need to Learn. Proceedings of the Eastern Family Economics and Resource Management Association, 102-109.

Danes, S. M., \& Hira, T. K. (1987). Money management knowledge of college students. The Journal of Student Financial Aid, 17(1), 4-16.

Financial Corps. (2014). Turkey advances national financial literacy strategy. Retrieved from http://financialcorps.com/turkey-advances-national-financial-literacy-strategy/

Gutter, M., \& Copur, Z. (2011). Financial Behaviors and Financial Well-Being of College Students: Evidence from a National Survey. Journal of Family and Economic Issues, 32(4), 699-714. http://dx.doi.org/10.1007/s10834-011-9255-2

Hair, J. F., Black, W. C., Babin, B. J., \& Anderson, R. E. (2009). Multivariate data analysis: A global perspective. (7th ed.). Upper Saddle River, NJ: Prentice Hall.

Hancock, A. M., Jorgsensen, B. L., \& Swanson, M. S. (2012). College students and credit card use: The role of parents, work experience, financial knowledge, and credit card attitudes. Journal of Family and Economic Issues, 34, 369-381. http://dx.doi.org/10.1007/s10834-012-9338-8

Hayhoe, C. R., Leach, L. J., Turner, P. R., Bruin, M. J., \& Lawrence, F. C. (2000). Differences in spending habits and credit use of college students. Journal of Consumer Affairs, 34, 113-133. http://dx.doi.org/10.1111/j.1745-6606.2000.tb00087.x

International Monetary Fund (IMF). (2013). Turkey: Increasing saving to reduce vulnerabilities. Retrieved from http://www.imf.org/external/pubs/ft/survey/so/2013/car122013a.htm

Joo, H., \& Grable, J. E. (2004). An exploratory framework of the determinants of financial satisfaction. Journal of Family and Economic Issues, 25, 25-50. http://dx.doi.org/10.1023/b:jeei.0000016722.37994.9f

Jorgensen, B. L., \& Savla, J. (2010). Financial literacy of young adults: The importance of parental socialization. Family Relations, 59(4), 465-478. http://dx.doi.org/10.1111/j.1741-3729.2010.00616.x

Kline, P. (2000). The handbook of psychological testing (2nd ed.). London: Routledge.

Lange, C., \& Byrd, M. (1998). The relationship between perceptions of financial distress and feelings of psychological well-being in New Zealand university students. International Journal of Adolescence and Youth, 7, 193-209. http://dx.doi.org/10.1080/02673843.1998.9747824

Lusardi, A., Mitchell, O., \& Curto, V. (2010). Financial literacy among the young. Journal of Consumer Affairs, 44(2), 358-380. http://dx.doi.org/10.1111/j.1745-6606.2010.01173.x

Lyons, A. (2004). A profile of financially at-risk college students. Journal of Consumer Affairs, 38(1), 56-80. http://dx.doi.org/10.1111/j.1745-6606.2004.tb00465.x 
Mandell, L. (2009). The financial literacy of young American adults: Results of the 2008 National Jump\$tart Coalition Survey of High School Seniors and College Students. Washington, DC: Jumpstart Coalition. Retrieved from http://www.jumpstart.org/assets/files/2008SurveyBook.pdf

Norvilitis, J. M., Merwin, M. M., Osberg, T. M., Roehling, P. V., Young, P., \& Kamas, M. M. (2006). Personality Factors, Money Attitudes, Financial Knowledge, and Credit-Card Debt in College Students. Journal of Applied Social Psychology, 36(6), 1395-1413. http://dx.doi.org/10.1111/j.0021-9029.2006.00065.x

Organisation for Economic Co-operation and Development (OECD). (2012). PISA 2012 financial literacy assessment framework. Retrieved from http://www.oecd.org/pisa/pisaproducts/46962580.pdf

Palmer, T. S., Pinto, M. B., \& Parente, D. H. (2001). College students' credit card debt and the role of public parental involvement: Implications for public policy. Journal of Public Policy \& Marketing, 20(1), 105-113. http://dx.doi.org/10.1509/jppm.20.1.105.17293

Sabri, M. F., MacDonald, M., Hira, T. K., \& Masud, J. (2010). Childhood Consumer Experience and the Financial Literacy of College Students in Malaysia. Family and Consumer Sciences Research Journal, 38(4), 455-467. http://dx.doi.org/10.1111/j.1552-3934.2010.00038.x

Sabri, M. F., Cook, C. C., \& Gudmunson, C. G. (2012). Financial well-being of Malaysian college students. Asian Ed and Dev Studies, 1(2), 153-170. http://dx.doi.org/10.1108/20463161211240124

Sevim, N., Temizel, F., \& Sayılır, Ö. (2012). The effects of financial literacy on the borrowing behaviour of Turkish financial consumers. International Journal of Consumer Studies, 36(5), 573-579. http://dx.doi.org/10.1111/j.1470-6431.2012.01123.x

Shim, S., Xiao, J. J., Barber, B. L., \& Lyons, A. C. (2009). Pathways to life success: A conceptual model of financial well-being for young adults. Journal of Applied Developmental Psychology, 30(6), 708-723. http://dx.doi.org/10.1016/j.appdev.2009.02.003

Shim, S., Barber, B. L., Card, N. A., Xiao, J. J., \& Serido, J. (2010). Financial Socialization of First-year College Students: The Roles of Parents, Work, and Education. J Youth Adolescence, 39(12), 1457-1470. http://dx.doi.org/10.1007/s10964-009-9432-x

Tang, T. L. (1995). The development of a short money ethic scale: Attitudes toward money and pay satisfaction revisited. Personality and Individual Differences, $19(6), \quad 809-816$. http://dx.doi.org/10.1016/s0191-8869(95)00133-6

Xiao, J. J., Tang, C., \& Shim, S. (2008). Acting for happiness: Financial behavior and life satisfaction of college students. Social Indicators Research, 92, 53-68. http://dx.doi.org/10.1007/s11205-008-9288-6

Xiao, J. J., Ahn, S. Y., Serido, J., \& Shim, S. (2014). Earlier financial literacy and later financial behaviour of college students. International Journal of Consumer Studies, 38(6), 593-601. http://dx.doi.org/10.1111/ijcs.12122

Volpe, R. P., Chen, H., \& Pavlicko, J. J. (1996). Personal investment literacy among college students: A survey. Financial Practice and Education, 6(2), 86-94.

Yesilada, F., \& Ucel, E. B. (2009). Financial Knowledge and financial responsibility: A study on adults in Turkey. Review of Business Research, 9(5), 114-119.

\section{Copyrights}

Copyright for this article is retained by the author(s), with first publication rights granted to the journal.

This is an open-access article distributed under the terms and conditions of the Creative Commons Attribution license (http://creativecommons.org/licenses/by/3.0/). 